\title{
The Cost of Democracy: The Determinants of Spending on the Public Administration of Elections
}

\author{
Alistair Clark \\ Newcastle University, UK \\ alistair.clark@ncl.ac.uk
}

\begin{abstract}
Managing the electoral process requires considerable administrative and organizational capacity. Poor performance can lead to voters being disenfranchised and the integrity and legitimacy of elections undermined. Providing sufficient capacity to manage a national electoral process is expensive. Little research assesses how much electoral democracy costs, and what drives those costs. These are crucial questions for democracies, political science and public administration. Using rare comprehensive data from Britain, this article's major contribution is to begin identifying some of the drivers impacting on the cost of electoral administration in advanced democracies. It presents an overview of influences on spending on electoral administration, before developing a multivariate model, utilising socio-economic, organizational and administrative data on election spending. It finds that costs in an important advanced democracy have been driven in a major national election by the need to provide capacity, notably on the ground close to electors.
\end{abstract}

Keywords: electoral administration; electoral integrity; elections 
Administering elections requires considerable organizational capacity. An electoral register must be established, ballot papers printed, staff employed and trained, and polling stations set up. Such capacity is expensive. Whether in democratizing countries or established democracies, little research assesses how much electoral democracy costs, and what drives the cost of administering national elections? These are important questions. The cost of politics is often criticized, without much understanding of the public goods such spending pays for. Yet, without considerable public spending on election administration, elections would either not be held, or electoral integrity would be open to question. Election administration therefore serves a vital democratic function. While a rare IFES/UNDP (2005) report did much to categorize and estimate election costs, it was less successful in examining how various costs were funded and capacity built on the ground. Others suggest that even within the same state, election costs are seldom recorded consistently, thereby limiting the potential for research (Montjoy, 2010).

The original contribution of this article is to explore the crucial relationship between spending on election administration and the organizational activities and capacity which that spending contributes to in an advanced democracy. Through an exploratory analysis, it aims to examine whether election costs are rising in advanced democracies, and to assess what the drivers of such spending are. It brings together rare but rigorous and extensive nationwide funding data from the UK Electoral Commission and UK government on three different electoral contests including the biggest test for electoral administrators of national elections. Britain is typical of many advanced democracies, notably the United States but also smaller democracies like Ireland, in that local officials have the main responsibility for delivering elections. Consequently, there is variation in standards of electoral administration and spending on such capacity. Britain is therefore an excellent case for building knowledge about the relationship between spending and organizational capacity in electoral administration. This 
evidence can be utilized to interrogate the relationship between spending and administrative capacity elsewhere.

The first section briefly addresses the relationship between public service capacity, resources and election administration. The second reviews the little known about spending on electoral administration. The third part describes the data deployed, while the fourth provides an overview of election spending before moving on to analyse election spending determinants through a public sector cost analysis of spending on the 2014 European elections in Britain. The conclusion reflects on the article's significance for scholarship on electoral administration and integrity.

\section{Capacity, Resources and Electoral Administration}

Public service capacity is normally defined in terms of the ability of bureaucracies to deliver their services. The question of resources is regularly highlighted as an important factor in doing so (Christensen and Gazley, 2008; Andrews and Boyne, 2010; Andrews et al., 2006).

Considerable organizational capacity is necessary to deliver elections (Alvarez and Hall, 2006; Montjoy, 2008). Pre-election, an electoral register must be compiled, poll workers recruited, voting equipment purchased and tested, ballot papers printed and polling station locations organized. During the campaign, if advance voting is permitted, this must be administered. On polling day, the election has to be run, staff turn up for work and be supervised, polling stations and ballot boxes secured and the count begun. Post-election, results need to be audited, challenges administered and lessons learned before the whole process begins again.

Most of these tasks, all vital to the smooth operation of elections, are periodic in nature. Electoral processes are run to short timescales, with the majority of staff being non-specialists 
recruited and trained only for the short-term conduct of the election (Clark and James, 2017a). Consequently, administrative efficiency can be prone to errors and mistakes, something which Birch (2011: 14 and 26) labels 'mispractice' and others consider 'malpractice' (Vickery and Shein, 2012). 'Mispractice' therefore equates to administrative inefficiencies, whereas 'malpractice' is defined as the 'manipulation of electoral processes and outcomes so as to substitute personal or partisan benefit for the public interest' (Birch, 2011: $14 \&$ 26). Difficulties can lead to perceptions of the electoral process being not uniform, and at worst, threatening the entire credibility or integrity of the process. Widespread scepticism and distrust about democratic processes means that such difficulties have the potential to further undermine confidence in political systems. Having the capacity to ensure the effective administration of the electoral process is crucial to maintain public confidence (Garnett, this volume).

\section{The Cost of Elections}

Election administrators must work with a wide range of resources when ensuring they have the capacity to prepare and deliver elections. These include human resources, technical capacity and expertise (Garnett; James; both this volume). The key resource enabling this capacity is the amount of money spent on administering elections.

The activities that contribute to running elections are expensive. For example, the 2010 Australian federal election cost upwards of $\mathrm{A} \$ 161 \mathrm{~m}$ to administer. This rose to $\mathrm{A} \$ 198 \mathrm{~m}$ in the 2013 federal contest. The 2011 Canadian election cost around $C \$ 291 \mathrm{~m}$, while the national election four years later had risen to $C \$ 443 \mathrm{~m}$ in a longer than normal election period. Even elections other than those to national parliaments are costly. The 2011 UK-wide referendum on electoral reform, a single-question ballot, is reported to have cost around $£ 75$ million, while just one American state, Wisconsin, spent \$37 million to administer five elections in 2012, 
including presidential primaries, the general election, and a number of elections associated with a recall contest (Australian Electoral Commission, 2011; 2013: 65; Elections Canada, 2011: 44-45; 2016: 35; Electoral Commission, 2012; Pew, 2012).

Little research examines the administrative cost of elections. Instead, this tends to be mentioned largely in passing, with the suggestion that insufficient spending has a negative impact on levels of performance. Birch (2011: 26) indicates a link between a lack of resources and incidences of electoral 'mispractice'. Pastor (1999) highlights a link in developing countries between weak spending on public administration and performance in the electoral process. Hall and Tokaji (2007) point to US electoral administration being underfunded, a point also strongly made by Gerken (2009) in arguing for better data collection to judge election quality. Alvarez and Hall (2006) show how insufficient funding leads to difficulties in recruiting poll workers. Low pay and a demanding workload mean that many fail to turn up to work, leading to unhelpful consequences for election quality. Money is certainly an important motivator for some poll workers (Clark and James, 2017a). Increasing demands from new legislation, technology and developing practice all stretch scarce resources even further-as do current austerity policies across many advanced democracies (Montjoy, 2010; James and Jervier, 2017).

The corollary is that increased spending should lead to better performance in election management. Highton (2006: 68) concludes his study of voting lines by arguing that 'administering elections requires ample resources. Administering them well requires even more'. Pastor (1999: 17-18) links an adequately resourced electoral commission with 'a far greater likelihood of conducting an election that is free and fair'. Most importantly, Hale and Slaton (2008: 843) suggest that increased US federal funding would improve local capacity in election administration. These assertions are seldom tested. In two rare exceptions, Clark (2014; 2017) uses extensive election funding data alongside a measure of election 
administration performance to argue that higher levels of election spending leads to higher levels of administrative performance. James and Jervier (2017) similarly suggest that better funded areas are more likely to undertake voter outreach activity. Even if performance gains in advanced democracies are likely to be relatively incremental, increased spending may lead to greater improvements in democratizing countries.

IFES/UNDP (2005: 15-16) have identified various costs involved in administering elections. At least three important distinctions are made. The first, and arguably key, distinction is between personnel costs and operational costs. Secondly, there is also an important difference between fixed costs and variable costs. The former relate to the day-to-day and ongoing running costs of electoral administration, independent of the costs of any specific election. Variable costs in contrast are those related to the actual conduct of a specific election. The third distinction in categorizing costs is between integrity costs and core costs. Integrity costs relate to voter and ballot security, whereas core costs are those relating to the general conduct of elections independent of any security or integrity measures that may be necessary. Separating out such costs is not always easy. As Montjoy (2010) found, even within the same US state, costs are not always recorded consistently or comprehensively. IFES/UNDP (2005: 15) similarly note that 'it is not always easy to split budgets and assign costs to different elections', a particular problem in many advanced democracies where often elections for multiple levels of government are held either concurrently or in the same electoral cycle.

In what is publicly reported, the difference between operational, variable and core costs is seldom clear. It is nevertheless possible to get some tentative comparative sense of the relationship between personnel and operational costs. Staffing accounts for a considerable part of spending on election administration, although there is variation in different jurisdictions. Around a third of the 2010 and 2013 Australian federal election budgets was spent on ‘employee expenses’ (Australian Electoral Commission, 2011; 2013). Of the US\$21.1 million 
spent on three elections in Wisconsin in 2012 around 59\% went on poll worker wages and staff salaries (Government Accountability Board, 2012). This is a similar proportion to the $60 \%$ noted by James (2012) in Virginia.

However, it is not always the case that even this general distinction between personnel and operational costs is easily available. Reports on Canadian elections include staffing and personnel costs alongside costs for services that might otherwise be classed as operational costs, such as printing electoral lists and renting polling stations (Elections Canada, 2011: 4445; 2016: 38). While labour costs were the largest item in Montjoy's (2010) description of election spending in Contra Costa County California, accounting for approximately $36 \%$ of costs in 2008, these were not available in his other case in Weld County, Colorado. Headline Australian election costs are typically reported with a public funding component included. This was approximately A\$53m in 2010 and A $\$ 58 \mathrm{~m}$ in 2013. Remove this from the total spent on national elections, and the proportion accounted for by employee costs rises to $47.5 \%$ in both 2010 and 2013, closer to the American examples above (Australian Electoral Commission, $2011 ; 2013){ }^{1}$

One way of establishing whether variations in election spending are on the high or low side is to establish how much is spent on election administration per elector. IFES/UNDP (2005: 21-22) provided a sense of how much elections cost to run in various types of democracies in the mid-2000s. They suggested that stable advanced democracies, such as the US and Western Europe, would spend between \$1-3 per elector. Democracies with less experience of multi-party competition they suggested would spend more, somewhere between \$3-7 per elector. Finally, in post-conflict or emerging transitional democracies, costs were likely to be higher still, somewhere above $\$ 8$ per elector. How reliable these estimates are is debatable. Analysis of the 2013 Australian and 2015 Canadian elections suggests an average cost per elector of approximately US\$13.50 in Canada (C\$17.04) and US\$7.40 in Australia 
(A \$9.48) (Australian Electoral Commission, 2013; Elections Canada, 2016). ${ }^{2}$ This is somewhat higher than IFES/UNDP estimated for stable democracies.

A related issue is whether election costs are increasing or declining. There are two sets of pressures. There is an increasing imperative in advanced democracies to reduce public spending. Spending on election administration is, consequently, far from a priority. For example, the Australian government and parliament regularly pressure the AEC to reduce costs (IFES/UNDP, 2005: 19). Elsewhere, minimizing costs is often given as a justification of holding different levels of election concurrently. The ending of various federal funding initiatives in the US are likely to have reduced the amount available for US electoral administration (Montjoy, 2010). Particularly, but not exclusively, in advanced democracies, length of electoral institutionalization is highlighted as important in building expertise and capacity while at the same time reducing costs (IFES/UNDP. 2005: 46-47). Conversely, a number of pressures are combining to increase the cost of elections. These include the need to pay reasonable wages to polling staff to ensure they turn up for work, the increasing need for new technology and expertise to support it, and the trend towards early or postal voting (IFES/UNDP, 2005; Montjoy, 2010). Technology, sometimes suggested by advocates as being the key to reducing costs, often ends up being more expensive than expected. Consequently, 'a perfect storm of election finance' has the potential to adversely affect election quality in advanced democracies (Montjoy, 2010: 873).

\section{Data and Approach}

Insights into these issues can be provided by examining spending on election administration in Britain. The key issue of concern is the funding of election organization, such as setting up polling stations and organizing the count, rather than the funding of electoral registration. 
While the importance of registration funding is recognized (Clark, 2014), it is typically the resourcing and capacity to deliver such practicalities that leads to the type of mispractice which can impact on public confidence on polling day, for instance through perceptions of fraud, lines at polling stations and difficulties in the count and tabulation process. ${ }^{3}$ Accordingly, spending on election practicalities is the immediate concern of the following analysis.

Like a number of advanced democracies, most obviously the USA, British elections are decentralized. They are run by Returning Officers (ROs), who are responsible for their delivery, alongside local authorities who muster the resources and personnel, and have discretion within statutory requirements for how elections are implemented. Consequently, considerable variation is evident to test these ideas against. British election administration has historically largely been taken for granted. This has gradually changed. There have been a number of high-profile difficulties in recent years which have served to highlight the sometimes fragile nature of election quality (Clark, 2014; 2015; 2017; Wilks-Heeg, 2009). James (2013) notes that British electoral administration is underfunded and that this impacts upon the service received by electors. It also impacts upon local authorities; they can wait up to two years to be refunded by government for spending on national elections. Clark's $(2014 ; 2017)$ examination of the relationship between election quality and spending in the 2009 European and 2010 general elections in Britain suggests that the more spent on electoral administration, the higher level of performance British returning officers have. These difficulties have highlighted the need for much more knowledge on British electoral administration with a view to informing broader debates.

Since the Political Parties, Elections and Referendums Act (PPERA) 2000, the UK has had an independent Electoral Commission responsible for oversight of numerous aspects of the electoral process. The Electoral Commission was given the role of overseeing election spending in the Electoral Administration Act (EAA) 2006. Consequently, information about 
election funding has gradually become publicly available. In parallel, recent UK governments have taken an interest in electoral administration. Labour governments between 1997-2010 sought to boost turnout (James, 2012). Conservative-led governments from 2010 have implemented individual electoral registration (IER), and also focused on combatting rare cases of electoral fraud. As part of this, the UK Cabinet Office has also been collecting and publishing data on electoral administration funding. Nonetheless, the practical delivery of electoral administration in Britain remains the responsibility of ROs and local government. The Electoral Commission has no formal powers of direction over either the ROs or the electoral registration officers (EROs) who are ultimately responsible for delivering the elections. ${ }^{4}$

Election funding in Britain is complex. Various bodies are involved. Funding is provided for national elections (General, European and Police and Crime Commissioners) by the UK government. Local authorities reclaim a specified amount after having incurred the expenditure. In general terms, for government-funded elections, the amount that can be recovered (Maximum Recoverable Amount, or MRA) is calculated for the local authority and based on the actual spending for the last equivalent election, with adjustments being made for various changes which may affect delivery such as an increased electorate, inflation, numbers of postal voters, changes in postage rates and so on. This formula and the allocations deriving from it can be controversial among election administrators. The costs of local elections and electoral registration more generally have to come from local authority budgets (Electoral Commission, 2010; Cabinet Office, 2016; James and Jervier, 2017). The UK Cabinet Office has provided additional funds for implementation of the new IER system. The UK Electoral Commission have also provided occasional funds, while the Scottish government and parliament now have powers over some elections, with Wales gradually also assuming such powers. Like other public organizations, the complexity and types of funding can be a 
difficulty, as can the predictability of funding streams and whether funds can be accessed when needed (Goetz and Patz, 2017).

Administrative data collected by public bodies provide advantages over social science surveys, not least in larger samples and more responses to work with. This can be powerful when combined with other administrative data (Connolly et al., 2016), the approach taken in this article. Response rates for the administrative data deployed here were very high. The 200711 surveys by the Electoral Commission had a response rate of around $80 \%$, while the 2014 Cabinet Office survey with 382 responses had a rate of $100 \%$ of local authorities who administer elections (Electoral Commission, 2010; Clark, 2016; Cabinet Office, 2016). The Electoral Commission surveys were designed with, and responses audited by, leading UK experts on public finance, the Chartered Institute of Public Finance and Accountancy. The data collected by the Cabinet Office was also extensive, although not directly comparable, since both organizations asked different questions and made different distinctions. The initial Electoral Commission data makes a distinction in its 2007-09 data between gross expenditure (subjective) and that net of income (objective). The former is utilised here. It does not make the same distinction in its 2009-11 data. The variable used for total spending in the 2014 Cabinet Office data is the total amount spent, calculated by adding individual items of expenditure. The data cited are from the 2008-09 and 2010-11 Electoral Commission surveys and the 2014 Cabinet Office survey. Although referred to where appropriate, the only alternative data on electoral spending between 2010-2016 was not directly comparable because of a lower response rate, meaningful coverage restricted to England and Wales, and a combination of electoral registration costs with the practicalities of running elections (James and Jervier, 2017). These difficulties notwithstanding, the data deployed are extensive and reliable for current purposes. 


\section{Overview}

Elections are widely perceived to be getting more expensive. Figure 1 highlights the cost of conducting elections and referendums in Britain from 2007-2017. This confirms that elections have become more expensive. The 2017 general election was estimated to have cost $£ 143 \mathrm{~m}$ to administer, a similar amount to the 2016 EU Referendum, while the conduct of elections in general election year 2010-11 was $£ 106.7 \mathrm{~m}$. Adjusting for inflation does not account for all of that increase. The Bank of England's inflation calculator suggests that in 2016 prices, the 2010 general election would only have cost around $£ 125.5 \mathrm{~m}$ to administer. ${ }^{5}$ The pattern of spending is higher in general elections and high turnout event electoral years, such as 2010-11, 2016 for the EU referendum and 2017 for the 'snap' general election. It is lower in years where electoral events with lower turnouts might be expected, such as 2009-10 and 2014 when European elections were held. Even in years with no major national electoral events such as 2008-09, electoral administration still incurs costs, whether for running local elections, by-elections or local referendums, albeit at a much lower level.

(Figure 1 about here)

(Table 1 about here)

This picture of increasing electoral costs is confirmed by the upper row in table 1 . This reports the cost per elector for each year considered. Albeit with year on year variations, the picture is also one of a steady increase in costs, to around $£ 3$ per elector in 2016-2017. Again, inflation does not wholly account for the difference between the 2010-11 and 2017 general elections years; at 2016 prices, the 2010 contest would have cost $£ 2.74$ instead of the around $£ 3$ that the 2016 events cost. Election administrators must plan for a certain level of turnout in 
each contest. When the actual level of turnout is factored in by considering cost per actual vote (bottom row in table 1), British elections appear even more expensive, with the 2011 and 2016 referendums all costing around $£ 4$ per voter. The figure for the 2014 European election suggests that there is an excess cost incurred by election administration in low turnout events. Electoral infrastructure still needs to be set up and paid for, even if high turnout is unlikely. Turnout in the 2014 European elections was only 35.5\%. Had turnout been higher, cost per vote would have been lower. ${ }^{6}$ Encouraging higher turnout is, from this perspective, not only politically desirable, but also more cost efficient.

(Table 2 about here)

Table 2 presents descriptive statistics for election spending by British local authorities. These figures do not include registration costs. Considerable variation exists in the three datasets, not least because they all use different measures of spending. Averages varied from $£ 359,537$ in the first dataset, to $£ 172,560$ for the actual costs of the 2014 European election. Crucially, while some councils spend little, in 2008-09 six councils spent over $£ 1$ million, while in 2010-11 five councils also spent over $£ 1$ million. Of these high-spending councils, only two spent over $£ 1$ million in both 2008-09 and 2010-11. Size seems crucial as these were the UK's largest local authority, Birmingham, and Scotland's largest city, Glasgow, which had large electorates of around 750,000 and 450,000 respectively at that time. Other local authorities spending over $£ 1$ million were either large cities or large rural areas which will incur extra expenditure because of the area to be covered. ${ }^{7}$ Bivariate correlations between the size of the local electorate, expressed as the number of electors per local authority, and total spent on electoral administration practicalities demonstrate strong, positive and statistically significant correlations at the $\mathrm{p}<.01$ level in all three datasets. James and Jervier (2017) also found 
variation in English and Welsh local authorities for a combination of registration and election practicalities, with a mean of around $£ 340,000$. Underlining the importance of size, Metropolitan district councils spent most on average, at around $£ 585,000$.

There is also considerable variation in spending per elector when examined by local authority. This varies by election. Based on the subjective total electoral administration spend, the 2008-09 average was $£ 3.09$, with a maximum of $£ 6.38$ and a standard deviation of $£ 1.05$. This fell in the 2010-11 data which covered the 2010 general election, to an average of $£ 2.45$ with a standard deviation of $£ 1.11$ and a maximum of $£ 7.18$. In 2014 , the average local authority spent $£ 1.54$ with the maximum spent per elector being $£ 6.43$ and a standard deviation of $£ 0.51$.

The distinction between staffing and operational spending is important. With its paperbased electoral system, the UK does not incur much costs for technology. Instead, paper ballots are issued, whether in polling places or by post, and counted by hand. Staff are crucial, whether they are polling clerks, presiding officers running polling stations, counting staff or supervisors employed temporarily for the elections, or the core elections services team. Core electoral services teams are small. The Electoral Commission (2012b: 15) suggests a total of around 1,300 people across Britain were employed in such teams in just under 400 local authorities between 2009-11. These had an average size of just under three people. Sizeable disparities were evident with Scottish teams averaging just under six members, and electoral services in England averaging half that at only 2.6. Interestingly, and potentially as a consequence of such disparities, Scottish electoral administration performed at a higher level in 2010 than its English and Welsh counterparts (Clark, 2015).

Staffing is expensive even if some temporary staff working on election day are only paid around minimum wage (Clark and James, 2017b). In the 2008-09 data, while some councils spent little, the mean amount spent on staffing was $£ 166,898$ with one council 
(Birmingham) spending over $£ 1.2$ million. In 2010-11, the period which covered the 2010 general election, while two councils spent under $£ 10,000$, at the other end of the scale, two councils again spent over $£ 1$ million on staffing (Glasgow and the London Borough of Kensington and Chelsea), with a mean of $£ 200,500$. By comparison, in the 2014 European election, staffing costs across Britain varied from as low as $£ 2,390$, with three councils spending below $£ 10,000$ on staffing, to a high of $£ 340,494$ (Glasgow) with a mean of $£ 60,217$. $^{8}$ Differences between the three datasets are likely to be accounted for by the fact that the 200809 and 2010-11 data covered whole years, while the 2014 data related just to the conduct of that specific election. Each dataset also categorized staff differently, with this being particularly disaggregated into different types of staff in the 2014 data.

(Figure 2 about here)

Staffing translates into a sizeable proportion of election administration spending across British local authorities. Figure 2 illustrates the variation in the proportion spent on staffing by councils in the 2014 data. The 2008-09 data indicates a mean of $45 \%$ of expenditure going on staffing, By contrast, the 2014 data in figure 2 has a mean of $35 \%$ and a standard deviation of 5.5. In 2014, the proportion spent on staffing ranged from, at the low end, around $20 \%$, to just over $60 \%$ at the high end. Most local authorities spent however somewhere between $30-40 \%$ of the total amount on staffing. This apparent reduction on spending on staffing between 200809 and 2014 may indicate pressure on staffing due to reduced budgets and austerity (Clark and James, 2016; James, this volume; James and Jervier, 2017). It is also likely to be an artefact of the differences in data collection. It provides nonetheless a useful benchmark for estimates of staffing electoral administration in advanced democracies. 
Local authorities have complained that the funding allocated by the government is insufficient to cover all the costs of running elections. Notably, local elections and registration are funded from local authority budgets, not by subventions from national government. James and Jervier (2017) suggest that 43\% of local governments had a shortfall in their 2010-16 data. The 2014 Cabinet Office data allow under and overspending to be estimated for the actual running of a major electoral event based on expectations about what those elections should cost (MRA). The average was a small underspend of less than $£ 2,000$, albeit with a standard deviation of $£ 21,614$. A total of 246 councils (or 66.5\%) underspent, while 124 (33.5\%) overspent, and 67 (or $18 \%$ ) overspent by $£ 10,000$ or more. The maximum overspend was over $£ 150,000$.

\section{Drivers of Electoral Authority (EA) Spending}

Despite having provided an overview of electoral administration spending, what the main drivers of such spending are remains obscure. One obvious point is that who is enfranchised, and the consequent size of the electorate being administered is likely to determine some of the costs incurred by electoral administrators. IFES/UNDP (2005: 17) suggest a number of factors that may drive costs. These include: the political environment, the number of elections to be funded, and whether these are concurrent or standalone; whether funding is for the Electoral Management Board (EMB) or the practical running of the elections; distinctions between core and integrity costs, and direct and diffuse costs incurred by different organizations involved in delivery; the funding source; and cost evolution over time to include investments and amortizations. Given the rarity of data on election spending, most of this information is likely to be extremely difficult to access. 
More practically, Hill (2012) proposes what she calls a public-sector cost model to examine the drivers of election administration finance. This is an ordinary least squares (OLS) regression with two groups of independent variables, which are run together. The first set relate to the cost or production function. These are things which have to be done to implement the election. She highlights the population being served, voting technologies, the need for bilingual election materials, costs imposed by legal requirements, levels of absentee voting, and polling sites as key issues perceived to be driving costs in her study of Californian election administration spending. The second set of independent variables relate to the demand function. This reflects 'income and socioeconomic factors that would potentially affect the demand for election administration' (Hill, 2012: 611). These include factors long associated with turnout: higher income; higher levels of education; age; and the ethnic make-up of the area being administered.

Some of the variables that Hill deploys, such as on voting machines and technology, or the Help America Vote Act (HAVA), have no British equivalents. Yet, other variables do, such as socio-economic demand variables, in addition to some of the production variables related to population and aspects of running the elections. The 2014 European parliament data are utilized for the subsequent analysis since they are most recent and up to date of the three datasets. Four production cost variables are deployed. Firstly, Hill (2012) suggests that the level of absentee ballots is important in determining some costs. The British equivalent is the number of postal voters per local authority in 2014. Secondly, whether or not the local authority is administering elections for a different level of government concurrently was also suggested to be important (Hill, 2012). Concurrent elections in Britain have been shown to impact negatively on election quality (Clark, 2017). A dummy variable for whether or not the local authority was holding another election at the same time as the 2014 European elections is therefore deployed. Thirdly, the number of physical polling locations needed to enable electors to cast their ballot is 
important in determining costs. The number of polling stations per local authority is utilised to capture this aspect. Finally, although Hill deploys both population size and precinct electorate as independent cost variables, this is not optimal since there is likely to be a correlation between both. The whole population is not registered to vote. Registered electorate is therefore likely to be more appropriate and utilised on its own.

In terms of demand variables, Hill (2012) deploys three which have a British equivalent. These are percentage minority population, percentage of population aged $65+$, and percentage of population who completed high school. Her fourth variable captured levels of local property taxation as a measure of community economic prosperity. In this study, the following are utilised as demand variables. The percentage non-white population captures any extra demands put on election administrators by, for example, having to provide bilingual material or particular cultural practices to look out for (Hill et al, 2017). The percentage of population aged $60+$, the percentage of students, and a composite variable of higher occupational groups intended to capture income and status are all deployed as proxies for populations often correlated with turnout. Gross value added (GVA), which measures local economic value, is deployed as a proxy for economic prosperity, based on 2014 estimates per elector in each local authority. All are measured at the level of the local authority, and taken from Census 2011 or other government data. ${ }^{9}$ The age variable is constructed by adding all age groups of $60+$. Similarly, the higher occupational variable combines levels of higher managerial, administrative and professional occupations with higher professional and large employer categories in the census data. The descriptive statistics for both production and demand variables are shown in table 3 .

(Table 3 about here) 
Two exploratory OLS regressions were undertaken. Descriptive statistics for both independent variables are also outlined in table 3.

Table 4 presents the results of these regressions. The first utilises the total spent as the dependent variable. Model fit was strong with an adjusted $\mathrm{R}^{2}$ of .902 . Each of the production cost variables was statistically significant. Numbers of postal voters, polling stations and the size of the electorate are all positively correlated with the total spent on electoral administration. For every extra polling station, the results suggest an additional $£ 988$ was spent in 2014 , while every additional voter led to a $£ 0.52$ increase and every additional postal voter to a $£ 0.82$ increase. Combined elections have two potential outcomes. Since the infrastructure is already in place, cost savings may exist if different level elections are held at the same time. Such an argument is often given to justify holding combined electoral contests. Alternatively, concurrent elections might imply greater costs since staff will need to work longer to count votes, more ballots need to be printed and so on (Clark, 2017). The results suggest evidence for the cost saving argument, with a negative relationship between combined elections and the amount spent.

(Table 4 about here)

By contrast, only two of the demand variables were statistically significant when regressed against total spending. Surprisingly the age variable suggests a negative relationship between the percentage of people aged $60+$ administered by the local authority, but as might be expected, a positive relationship between levels of higher status occupations in that local authority and election administration spending. ${ }^{10}$ The ethnicity, students/education and GVA per head variables were not statistically significant. ${ }^{11}$ 
To corroborate these findings, the second regression followed Hill's (2012) use of the total amount spent per elector as the dependent variable. There were three main differences in the results to this analysis from the first model. Firstly, the model was a weaker fit at .554 for the adjusted $\mathrm{R}^{2}$. Secondly, of the production variables, the amount of postal voters was no longer significant. Thirdly, with the demand variables, both the age and higher status variables drop out of significance. Instead, the minority variable becomes statistically significant at the $\mathrm{p}<.01$ level, and evidences a weak positive correlation with spending per elector, echoing Hill's (2012) Californian finding. GVA also becomes statistically significant at $\mathrm{p}<.01$ suggesting greater spending in better off areas, albeit in a different way to the regression considering total spending which highlighted higher status groups.

Both analyses were also run using electorate density, expressed as the number of electors per hectare, as an independent production cost variable instead of the size of the local authority electorate. This was something Hill (2012) was unable to test. This attempted to capture the interaction between electorate and the size of area administered, offering a rough approximation of the effects of administering elections for an urban or rural local authority. Economies of scale might have been evident in highly populated urban areas, which are less easy to benefit from with more dispersed electorates. The findings (not shown for space reasons) were not statistically significant.

Focusing only on those variables which are significant in both analyses suggests that the production side of the equation is, at least tentatively, more likely to drive election spending by local authorities. Numbers of polling stations, whether combined elections are held, and the size of the electorate were all crucial as production costs in both analyses. Hill's (2012) account made a similar finding about the importance of production costs. Spending on election administration therefore can be argued to provide crucial capacity to run these contests in terms of the physical presence of providing election infrastructure, but this can cut in different 
directions as there may be cost savings to be made in places. In terms of demographics, what matters in determining this capacity seems to be the size of the electorate, rather than necessarily its composition, although there is the suggestion that more is spent in better-off areas, albeit with different findings from the demand side in both models.

\section{Conclusion}

Cowling (2013) observes that election administration 'is a massive, extraordinary and complex operation: the biggest manifestation of civil society any of us are likely to see'. It is a fundamental yet not well understood area of electoral politics. Integration of approaches to the capacity of public administration with extensive, and rigorous nationwide administrative data on election spending, which have not been previously utilized for academic research, enables some very important insights into this vital democratic function. These include the proportion spent on staffing elections, and the fact that costs in one significant advanced democracy have been driven in an important national election by the need to provide capacity, notably on the ground close to electors. This helps underline the argument that greater investment in electoral administration would improve capacity to deliver higher quality elections. It provides benchmarks which can be tested in other jurisdictions and also helps address questions regarding the perceived cost pressures on electoral administrators in advanced democracies.

The article has also opened a range of important issues that require further research. Questions abound. For example, might other influences on spending on election administration that be usefully included in a more advanced public cost model of election financing? Comparatively, are the benchmarks on electoral costs for different democracies established by IFES/UNDP (2005) in need of updating at the international level. The figures highlighted in this paper, for Britain and elsewhere, suggest that they need rethought and that cost pressures 
are more than just the result of inflation even where election administration is well established. This may be even more the case in less advanced democracies.

The article underlines the importance of two further issues, even if somewhat indirectly. The first is the urgent need for greater transparency, both domestically and internationally, around the funding of election administration. Such spending provides capacity to administer such contests. Withholding or misallocating funds affects the delivery of elections. Only with greater transparency can this, to some degree at least, be diagnosed. Even if after the event, it provides the opportunity to make future funding decisions on as equitable a basis as possible. Secondly, as the data deployed here demonstrate, there is a pressing need to develop common standards for accounting and recording spending on elections. In the three datasets utilised above, two collected by the same organization and all part of public administration in the same state, three different sets of distinctions have been made. This impacts upon the ability to compare developments over time both within and across countries. Developing consistent approaches to recording such data is important if analysts are to understand the funding of elections, the capacity it brings and its impact on election integrity and performance.

\section{Acknowledgments}

I am grateful to Stuart Wilks-Heeg, Holly Ann Garnett, Toby James, Staffan Darnolf and IPSR's reviewers for comments. The usual disclaimer applies.

\section{Funding}

This research received no specific grant from any funding agency in the public, commercial or not-for-profit sectors.

\section{References}


Alvarez, R. Michael.and Hall, Thad E. (2006) 'Controlling Democracy: The Principal-Agent Problems in Election Administration', Policy Studies Journal, 34: 4, 491-510.

Andrews, Rhys, Boyne, George A. and Walker, Richard M. (2006) 'Strategy Content and Organizational Performance: An Empirical Analysis', Public Administration Review, 66: 1, 52-63.

Andrews, Rhys, and Boyne, George A. (2010) 'Capacity, Leadership and Organizational Performance: Testing the Black Box Model of Public Management', Public Administration Review, 70: 3, 443-454.

Australian Electoral Commission (2011) 'Electoral Pocketbook 2011 - 3 The Electoral Process', http://www.aec.gov.au/About_AEC/Publications/electoral_pocketbook/2011/epcosts.htm [25/3/2014].

Australian Electoral Commission (2013) Electoral Pocketbook, Canberra: Australian Electoral Commission.

Birch, Sarah (2011) Electoral Malpractice, Oxford: Oxford University Press.

Cabinet Office (2016) The Costs of the 2014 European Parliamentary Elections, London: Cabinet Office.

Christensen, Robert K. and Gazley, Beth (2008) 'Capacity for Public Administration: Analysis of Meaning and Measurement', Public Administration and Development, 28: 4, 265-279.

Clark, Alistair (2014) 'Investing in Electoral Management' in P. Norris, R. Frank \& F. Martinez I Coma (eds.) Advancing Electoral Integrity, New York: Oxford University Press, pp165-188.

Clark, Alistair (2015) 'Public Administration and the Integrity of the Electoral Process in British Elections', Public Administration, 93, (1), pp86-102. 
Clark, Alistair (2017) 'Identifying the Determinants of Electoral Integrity and Administration in Advanced Democracies: The Case of Britain', European Political Science Review, 9, (3), $\mathrm{pp} 471-492$.

Clark, Alistair and James, Toby S. (2016). An Evaluation of Electoral Administration at the EU Referendum. London: Electoral Commission.

Clark, Alistair and James, Toby S. (2017a) 'Poll Workers', in P. Norris \& A. Nai (eds.) Election Watchdogs: Transparency, Accountability and Integrity, New York: Oxford University Press, pp144-164.

Clark, Alistair and James, Toby S. (2017b) 'Why Volunteer? Poll Workers' Motivations for Public Service on Election Day'

Connolly, Roxanne, Playford, Christopher. J., Gayle, Vernon, and Dibben, Chris (2016) 'The Role of Administrative Data in the Big Data Revolution in Social Science Research', Social Science Research, 59, pp1-12.

Cowling, David (2013) 'What Price Democracy? Counting the Cost of UK Elections', http://www.bbc.co.uk/news/uk-politics-24842147 $8^{\text {th }}$ November.

Elections Canada (2011) Report of the Chief Electoral Officer of Canada on the $41^{\text {st }}$ General Election of May 2 2011, Ottawa: Elections Canada.

Elections Canada (2016) Report on the 42nd General Election of October 19, 2015, Gatineau: Elections Canada.

Electoral Commission (2010) The Cost of Electoral Administration in Great Britain: Financial Information Survey 2007-08 and 2008-09, London: Electoral Commission.

Electoral Commission (2012a) Costs of the May 2011 Referendum on the UK Parliamentary Voting System, London: Electoral Commission.

Electoral Commission (2012b) The Cost of Electoral Administration in Great Britain: Financial Information Surveys 2009-10 and 2010-11, London: Electoral Commission. 
Garnett, Holly Ann (XXX) 'Evaluating Election Management Body Capacity'

Gerken, Heather K. (2009) The Democracy Index: Why Our Election System is Failing and How to Fix It, Princeton: Princeton University Press.

Goetz, Klaus H. and Patz, Ronny (2017) Resourcing International Organizations: Resource Diversification, Organizational Diversification and Administrative Governance', Global Policy, 8, Supplement 5, pp5-14.

Government Accountability Board Wisconsin (2012) 'G.A.B. Releases 2012 Election Cost Data', http://gab.wi.gov/node/2569 [25th March 2014].

Hale, Kathleen and Slaton, Christa Daryl (2008) 'Building Capacity in Electoral Administration: Local Responses to Complexity and Interdependence', Public Administration Review, 68: 5, 839-849.

Hall, Thad and Tokaji, Daniel (2007) 'Money For Data: Funding the Oldest Unfunded Mandate', Equal Vote Blog, Election Law at Moritz, http://moritzlaw.osu.edu/blogs/tokaji/2007_06_01_equalvote_archive.html [8th May 2013].

Highton, Benjamin (2006) 'Long Lines, Voting Machine Availability, and Turnout: The Case of Franklin County, Ohio in the 2004 Presidential Election', PS: Political Science and Politics, 39: 1, 65-68.

Hill, Eleanor, Sobolewska, Maria, Wilks-Heeg, Stuart, and Borkowska, Magda (2017) 'Explaining electoral fraud in an advanced democracy: Fraud vulnerabilities, opportunities and facilitating mechanisms in British elections', British Journal of Politics and International Relations, 19, 4, pp772-789.

Hill, Sarah A. (2012) 'Election Administration Finance in California Counties', American Review of Public Administration, 42, 5, pp606-628. 
House of Commons (2016) EU Referendum - The Count, Briefing Paper 7588, London: House of Commons Library.

IFES/UNDP (2005) Getting to the CORE: A Global Survey on the Cost of Registration and Elections, New York: UNDP.

James, Toby S. (2012) Elite Statecraft and Election Administration: Bending the Rules of the Game? Basingstoke: Palgrave.

James, Toby S. (2013) 'Fixing Failures of U.K. Electoral Management', Electoral Studies, 32: 4, pp597-608.

James, Toby S. and Jervier, Tyrone (2017) 'The Cost of Elections: The Effects of Public Sector Austerity on Electoral Integrity and Voter Engagement', Public Money and Management, 37, (7), pp461-468.

James, Toby S. (XX) 'Building Better Elections: The Role of Human Resource Management Practices',

Lobel, Mark (2017) ‘Could This General Election be the UK's Most Expensive?', BBC News, http://www.bbc.co.uk/news/election-2017-39882972, $12^{\text {th }}$ May [1/June/2017].

Montjoy, Robert S. (2008) 'The Public Administration of Elections', Public Administration Review, 68: 5, 788-799.

Montjoy, Robert S. (2010) 'The Changing Nature ... and Costs ... of Electoral Administration', Public Administration Review, 70: 6, 867-875.

Pastor, Robert A. (1999) 'The Role of Electoral Administration in Democratic Transitions: Implications for Policy and Research', Democratization, 6: 4, pp1-27.

Pew Charitable Trusts (2012) 'Wisconsin Election Costs', http://www.pewstates.org/research/analysis/wisconsin-election-costs-85899424927 [25/3/2014]. 
Vickery, Chad and Shein, Erica (2012) Assessing Electoral Fraud in New Democracies: Refining the Vocabulary, Washington DC: IFES.

Wilks-Heeg, Stuart (2009) 'Treating Voters as an Afterthought? The Legacies of a Decade of Electoral Modernisation in the United Kingdom', Political Quarterly, 80: 1, pp101-110. 
Figure 1: British Election / Referendum Costs, 2007-2017 (£m)

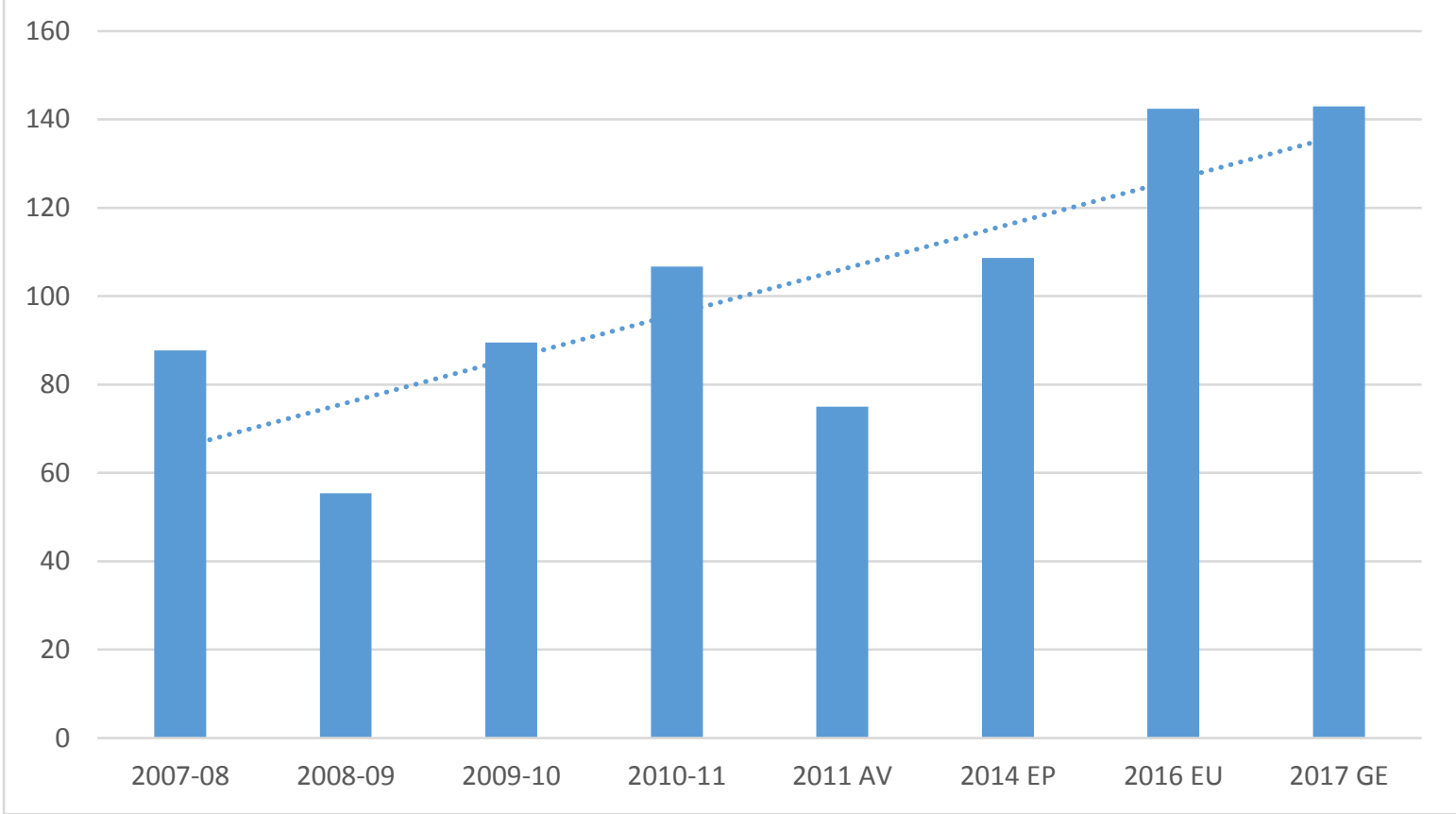

Sources: Electoral Commission (2010, 2012a, b) Cabinet Office, 2016; House of Commons, 2016; BBC, 2017. Note: the 2011 AV, 2014 EP, 2016 EU and 2017 GE estimates include Northern Ireland.

Table 1: British Election / Referendum Costs, Per Elector \& Vote 2007-2017 (£s)

\begin{tabular}{|lc|c|c|c|c|c|c|c|c|}
\hline & $\begin{array}{c}2007- \\
08\end{array}$ & $\begin{array}{c}2008- \\
09\end{array}$ & $\begin{array}{c}2009- \\
10\end{array}$ & $\begin{array}{c}2010- \\
11\end{array}$ & $\begin{array}{c}2011 \\
\text { AV }\end{array}$ & $\begin{array}{c}2014 \\
\text { EP }\end{array}$ & $\begin{array}{c}2016 \\
\text { EU }\end{array}$ & $\begin{array}{c}2017 \\
\text { GE }\end{array}$ \\
\hline $\begin{array}{l}\text { Cost per } \\
\text { elector }\end{array}$ & 1.72 & 1.19 & 1.98 & 2.33 & 1.65 & 2.33 & 3.06 & 3.05 \\
\hline $\begin{array}{l}\text { Cost per } \\
\text { vote }\end{array}$ & - & - & - & - & 3.90 & 6.57 & 4.24 & 4.44 \\
\hline
\end{tabular}

Sources: Electoral Commission (2010: 32, 2012a, b; 31) Cabinet Office, 2016 \& author's calculations. Note: the 2011 AV, 2014 EP, 2016 EU and 2017 GE estimates include Northern Ireland. 
Table 2: Total Amounts Spent on Electoral Administration by Local Authorities (£s)

\begin{tabular}{|l|c|c|c|c|c|}
\hline & Min & Max & Mean & S.D. & N \\
\hline $2008-09$ & 151 & $2,057,303$ & 359,537 & 254,137 & 298 \\
\hline $2010-11$ & 0 & $1,443,560$ & 289.804 & 204,652 & 306 \\
\hline 2014 & 10,730 & 971,035 & 172,560 & 117,739 & 379 \\
\hline
\end{tabular}

Note: 2008-09 Subjective expenditure, Total Electoral Administration Total; 2010-11 Conducting Elections Total; 2014 Total Spend, Northern Ireland excluded.

Figure 2: \% of Electoral Administration spending on staffing, 2014

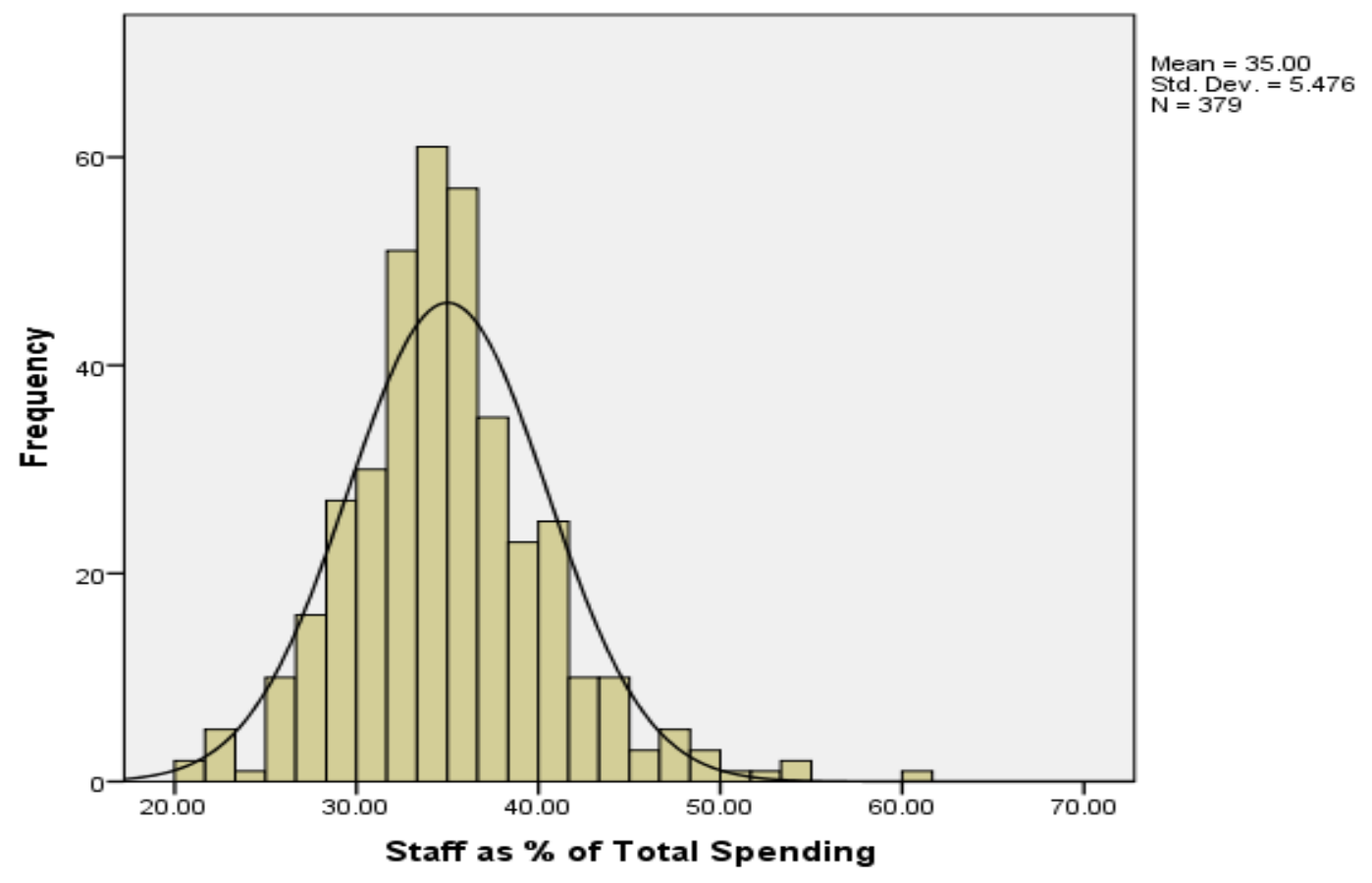


Table 3: Descriptive Statistics

\begin{tabular}{|c|c|c|c|c|c|}
\hline & $\mathrm{N}$ & Minimum & Maximum & Mean & Std. Deviation \\
\hline \multicolumn{6}{|l|}{ Production Cost } \\
\hline Postal Voters & 381 & 42 & 92795 & 18932.18 & 13510.734 \\
\hline Polling Stations & 381 & 4 & 467 & 100.67 & 63.019 \\
\hline Combined elections & 381 & 0 & 1 & - & - \\
\hline Electorate & 381 & 1669 & 715014 & 118740.4 & 78103.7 \\
\hline \multicolumn{6}{|l|}{ Demand } \\
\hline Age $60+\%$ & 380 & 8.40 & 38.00 & 23.9755 & 5.03456 \\
\hline Minority non-white \% & 380 & .80 & 71.30 & 9.6971 & 12.27034 \\
\hline Higher status composite \% & 380 & 8.00 & 70.90 & 20.5255 & 7.65143 \\
\hline Full time students \% & 380 & 1.20 & 27.70 & 7.9511 & 3.63337 \\
\hline Gross Value Added per elector & 380 & .01 & 7.51 & .0526 & .38428 \\
\hline \multicolumn{6}{|l|}{ Independent } \\
\hline Total Spend (£) & 379 & 10730 & 971035 & 172560 & 117739 \\
\hline Total Spend per elector $(£)$ & 379 & 0.74 & 6.43 & 1.54 & 0.51 \\
\hline
\end{tabular}

Table 4: Regressions on 2014 European Election Spending

\begin{tabular}{|c|c|c|c|c|c|c|}
\hline & $\mathrm{B}$ & (S.E.) & Beta & B & (S.E.) & Beta \\
\hline & \multicolumn{3}{|c|}{ Total Spend } & \multicolumn{3}{|c|}{ Total Spend /Elector } \\
\hline Constant & 36293.225 & 20475.378 & & $1.607 * *$ & .190 & \\
\hline $\begin{array}{l}\text { Production } \\
\text { Cost }\end{array}$ & & & & & & \\
\hline $\begin{array}{l}\text { Postal } \\
\text { Voters }\end{array}$ & .823 & .311 & $.094 * *$ & $3.385 \mathrm{E}-6$ & .000 & .089 \\
\hline $\begin{array}{l}\text { Polling } \\
\text { Stations }\end{array}$ & 988.245 & 71.262 & $.530 * *$ & .004 & .001 & $.521 * *$ \\
\hline $\begin{array}{l}\text { Combined } \\
\text { elections }\end{array}$ & $\begin{array}{c}- \\
66842.380 \\
\end{array}$ & 4701.009 & $-.281 * *$ & -.602 & .044 & $-.581 * *$ \\
\hline Electorate & .524 & .079 & $.348 * *$ & $-4.250 \mathrm{E}-6$ & .000 & $-.648 * *$ \\
\hline Demand & & & & & & \\
\hline Age $60+\%$ & -1496.639 & 631.911 & $-.064 *$ & .007 & .006 & .072 \\
\hline $\begin{array}{l}\text { Minority } \\
\text { non-white } \\
\%\end{array}$ & 84.555 & 250.909 & .009 & .007 & .002 & $.160 * *$ \\
\hline $\begin{array}{l}\text { Higher } \\
\text { status } \\
\text { composite } \\
\%\end{array}$ & 1023.003 & 274.641 & $.066 * *$ & .001 & .003 & .018 \\
\hline $\begin{array}{l}\text { Full time } \\
\text { students } \%\end{array}$ & 187.873 & 665.778 & .006 & -.009 & .006 & -.067 \\
\hline $\begin{array}{l}\text { GVA per } \\
\text { elector }\end{array}$ & -9217.823 & 5334.888 & -.030 & .156 & .050 & $.117 * *$ \\
\hline Adj. R ${ }^{2}$ & .902 & & & .554 & & \\
\hline $\mathrm{N}$ & 378 & & & 378 & & \\
\hline
\end{tabular}

Note: Statistical significance $* * \mathrm{p}<0.01 ; * \mathrm{p}<0.05$. 


\footnotetext{
${ }^{1}$ I thank one of IPSR's referees for this observation.

${ }^{2}$ Converted on $14 / 7 / 2017$ at the rates of $\mathrm{A} \$ 1=\mathrm{US} \$ 0.78$ and $\mathrm{C} \$ 1=\mathrm{US} \$ 0.79$.
}

${ }^{3}$ In some countries, there can be added complexity because a variety of organizations may be involved in delivery, making it hard to account for various costs.

${ }^{4}$ Different arrangements exist in Scotland and Northern Ireland, with the Scottish Electoral Management Board (EMB), and the Electoral Office of Northern Ireland (EONI) both having some responsibilities but with local authorities effectively responsible on the ground for delivery.

${ }^{5}$ See: http://www.bankofengland.co.uk/education/Pages/resources/inflationtools/calculator/default.aspx $[14 / 7 / 2017]$

${ }^{6}$ Calculations for spending per vote are not made for 2007-2011 because they each cover a year's worth of electoral administration spending and are not specific to actual elections. The 2011 and 2016 referendums, 2014 European and 2017 general elections are estimates for specific events and cost per elector is both a possible and meaningful indicator. Estimates here for the 2014 European election differ from the Cabinet Office estimate. The calculation is based on a total amount of $£ 108.7$ million divided by a UK electorate of 46.5 million and 16.5 million votes cast. The Cabinet Office (2016: 25) estimates are cost per elector of $£ 1.47$ and cost per vote of $£ 4.12$. ${ }^{7}$ The others were in 2008-09, Wandsworth, Liverpool, Sheffield and Bradford, while in 2010-11 they were Ealing, Durham and Fife.

${ }^{8}$ 2008-09 variable - subjective total electoral administration employees total. 2010-11 variable - Total Electoral Administration Employees (TEAEmpTotal). The 2014 variable is a composite of costs for the various staff categories contained in the data - presiding officers, poll clerks etc - and the associated expenses involved in staffing elections such as travel \& subsistence and superannuation.

${ }^{9} \mathrm{GVA}$ data is from the ONS dataset 'Regional Gross Value Added (Income Approach) by Local Authority in the UK' which estimates local GVA between 1997-2015.

${ }^{10}$ This may be a product of electorate size. The relationship between electorate size, density and election funding requires further research, particularly into the MRA formula used by government to calculate election funding.

${ }^{11}$ Both regressions were also run with Total GVA per local authority as the independent variable. The results confirmed the pattern of strength and significance for GVA per elector as reported in table 4. 
Dr. Alistair Clark is Reader in Politics at Newcastle University, UK. His research interests include electoral integrity and political parties. 